\title{
Definition of the Eifelian-Givetian Stage boundary
}

The boundary for the Eifelian-Givetian Stage Global Stratotype Section and Point (GSSP) in the Middle Devonian has been ratified by the ICS and the IUGS and is placed in a section at Jebel Mech Irdane in the Tafilalt of Morocco. The position of the boundary was selected by the Subcommission on Devonian Stratigraphy in 1992 to coincide with the level at which Polygnathus pseudofoliatus changes to Polygnathus hemiansatus as described herein. The boundary corresponds closely with the base of the goniatite Maenioceras Stufe used as a Middle Devonian division, and with the entry of the dacryoconarid Nowakia otomari. Although spores are not described from the section owing to thermal modification, the level is thought to lie below the appearance of Geminospora lemurata the entry of which has been widely used elsewhere in spore-bearing regions as a guide to the Givetian. Comments are made on the relations of the GSSP level to the associated Kačák or otomari Event.

\section{Introduction}

The Devonian System has been divided into three series, Lower, Middle and Upper, essentially since the Bologna Congress of Geologists in 1888 recommended this pattern for all geologic systems. The Subcommission on Devonian Stratigraphy (SDS) has already recommended Global Stratigraphic Section and Point (GSSP) boundaries for both the upper and lower limits of the Middle Devonian and these have been ratified by the ICS and IUGS (Ziegler and Klapper, 1985; Klapper and others, 1987). The chronostratigraphic division of the Middle Devonian is into a lower Eifelian stage, and an upper Givetian stage. This paper gives details of the GSSP recommended by SDS to define the base of the Givetian: it was formally ratified by IUGS at a London meeting of the Executive Committee held in January 1994.

The classic area for the Givetian is in the Ardennes of southern Belgium and northern France where the term Givetien has been available for rather over a century being introduced by Gosselet (1879) for the Calcaire de Givet or Calcaire à Stringocephalus burtini. However, even in the type area there has been no consistent definition of a base (Errera and others, 1972). Some have placed the lowest 5-6 m of dark bluish limestones in the Eifelian (locally Couvinian, Carte géologique détaillé de la France, Givet, 1970); and oth-
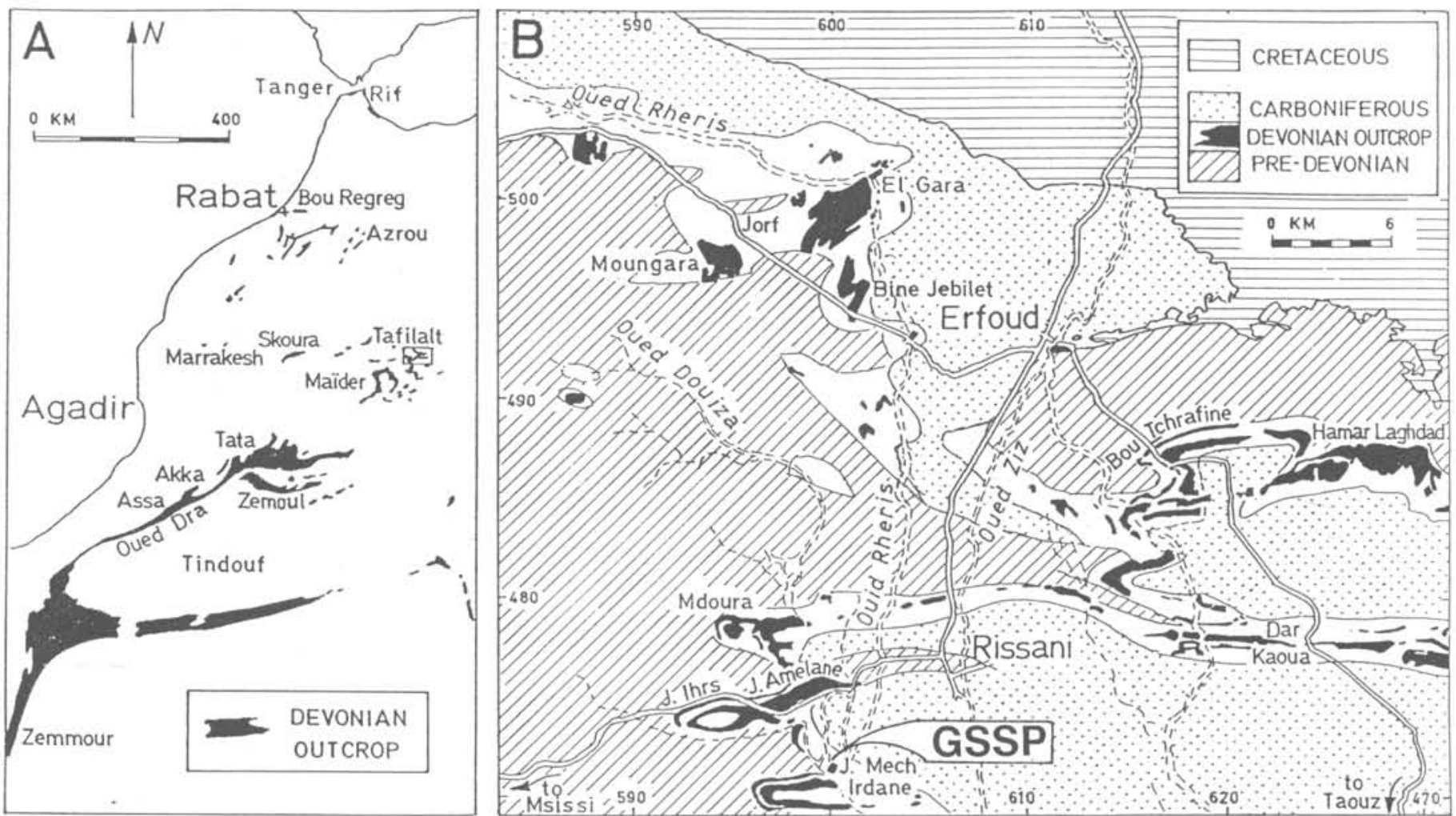

Figure 1

A, Map showing the outcrop of Devonian rocks in Morocco and adjacent areas showing by a small rectangle in the Tafilalt the area covered in the detailed map.

B, Detailed map showing the geology of the Erfoud area and the position of the Eifelian-Givetian GSSP at Jebel Mech Irdane. (Based on maps published by the Ministère de l'Energie et des Mines, Rabat; after Becker and House, 1994a). 

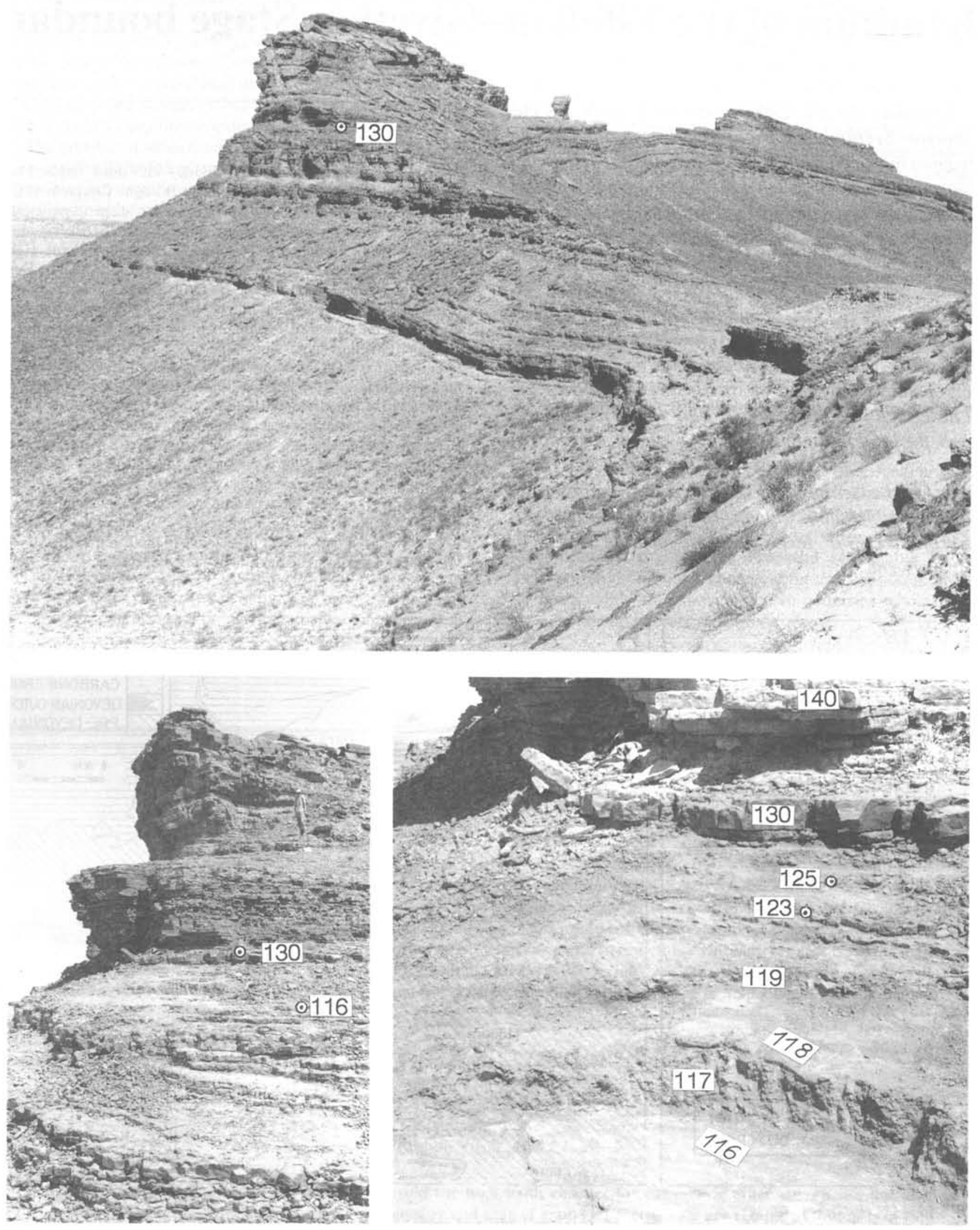

Figure 2 Photographs illustrating the position of the GSSP Eifelian-Givetian boundary level, Bed 123, at Jebel Mech Irdane, 25 $\mathrm{km} \mathrm{SSW}$ of Erfoud and $12 \mathrm{~km} \mathrm{SW}$ of Rissani, Tafilalt, Morocco (Photos by $\mathrm{OH}$ Walliser). 
ers not (Bultynck, 1970, 1987). Another boundary used has been the entry of Stringocephalus burtini, which appears above the base of the Givet Limestone in the type area, and in the Loogh Formation in the Eifel Mountains of adjacent Germany (Struve, 1982a). With the increasing dominance of highly discriminating goniatite biostratigraphy in more pelagic facies, especially developed in Germany east of the Rhine, other faunal guides have been used such as the Zone of Cabrieroceras crispiforme (= rouvillei) but that species group is now known to occur as early as the conodont australis Zone (Becker and House, 1994a) and well within the Eifelian of the revised definition. Another index, Maeneceras (now Maenioceras) undulatum was suggested by Schmidt (1958, p.309), and that closely corresponds to the boundary now recommended.

However it has been the growth in conodont studies which has contributed most to the detailed correlation of Eifelian-Givetian boundary sections internationally and demonstrated the need for clear definition. The sequence of the classic Ardennes area was described by Bultynck $(1970,1987)$ and was clarified by his work in Morocco. The sequence of the Eifel area was described by Weddige (1977, 1988, 1989). This led to proposals that the boundary should be related to a level in an evolutionary sequence where Polygnathus pseudofoliatus changes to Polygnathus hemiansatus by a change from a steep outer anterior platform margin to an obliquely declining one. Potential sections had been considered in Germany and Morocco. After much discussion, the SDS received three formal submissions for the GSSP, all in southern Morocco, at Ou Driss, Bou Tchrafine and Jebel Mech Irdane. After all three were visited by the SDS in December 1991 all but Jebel Mech Irdane were withdrawn and this was unanimously accepted at a Business Meeting and accepted in the subsequent postal vote with 20 votes in favour and one against. The advantages of the Moroccan sections lie in their association with a wide range of other faunal elements likely to be of value for international correlation. Some details relating to the defining characteristics are given later in this account.

In parallel with the work of the SDS on international correlation at about this level has been the recognition of the importance of a widespread hypoxic sedimentary perturbation near the EifelianGivetian boundary which has been named the Kačák Event (House, 1985) or, after associated faunal indicators, the otomari or rouvillei Event (Walliser, 1984, 1985). At Jebel Mech lrdane it is represented

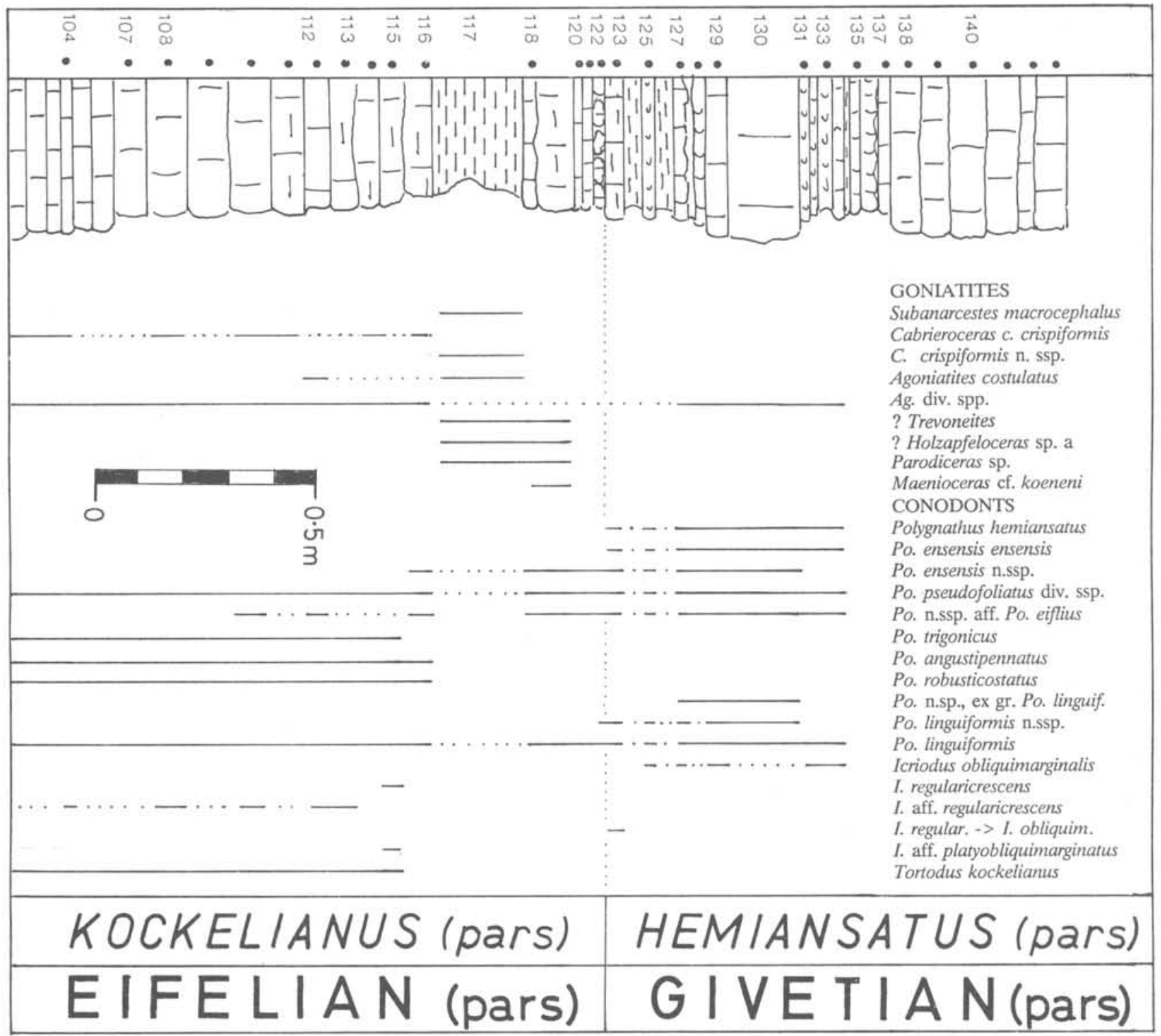

Figure 3 Table showing the ranges of taxa across the Eifelian-Givetian boundary at Jebel Mech Irdane (Modified from Walliser, 1991), 
by a black shale intercalation near the level of the proposed definition. Some comments on this are made later.

\section{Recommended stratotype}

The recommended level for the GSSP to define the base of the Givetian is at Jebel Mech Irdane, $25 \mathrm{~km} \mathrm{SSW}$ of Erfoud and $12 \mathrm{~km} \mathrm{SW}$ of Rissani, Morocco (Figure 1) (1:100,000 Carte du Maroc, Feuille NH-30-XX-2, Erfoud, Lambert's coordinates: $x=5992, y=4706$ ). Jebel Mech Irdane translates as 'Hill of the Little Mouse'. The locality is about $6 \mathrm{~km}$ from the metalled Msissi road west of Rissani (Figure 1) and easily reached by four-wheel-drive vehicles. The ridge there gives continuous exposure. The proposed level is at the base of Bed 123 in the succession (Figures $2 a-c$ ).

The ridge of Jebel Mech Irdane is $4 \mathrm{~km}$ long and exposes a full and fossiliferous succession from the Emsian into the Frasnian. Exposure is complete and each bed may be examined in numerous places along the ridge. The actual proposed stratotype sequence is on the gently sloping western side of a knoll which gives easy access to all beds. Around the GSSP the section is primarily one of pelagic calcilutites and micrites with shales at the Kačák Event level. The detailed faunal record of the section is given in Figure 3 (modified from Walliser, 1991). The area is extremely isolated and unlikely to be threatened in any way. Access is available to scientists but authorisation papers should be sought from the Bureau of Mines, Rabat.

The boundary proposed represents the level at which Polygnathus pseudofoliatus changes to Polygnathus hemiansatus by a change from a steep outer anterior platform margin to an obliquely declining one and in particular the new form recognised as Polygnathus hemiansatus; this level, of Bed 123 at Jebel Mech Irdane, is within the upper Freilingen Formation in the Eifel (Bultynck and others, 1991). The Stringocephalus entry level in the Eifel lies at the overlying Ahbach-Loogh boundary, thus the range of the true Stringocephalus is wholly within the Givetian under the proposed definition. The main development of black limestones in the Odershäuser Formation of the eastern Rhenish Schiefergebirge lies below the new boundary (Bultynck and others, 1991; Weddige, 1990), as does much of the Kačák Member of the Srbsko Formation in the Prague Basin; these units correspond to the entry of Nowakia otomari and mark the otomari Event (Walliser, 1985) or Kačák Event (House, 1985), and hence to the upper part of the classical crispiforme (= rouvillei) Zone (MD-I-F2 of Becker and House, 1994a), the top part of which represents a marked extinction event for goniatites (House, 1985, 1993; Becker and House, 1994a). The latter seems to lie within beds 117 and 119 in the Mech Irdane section. The proposed boundary level appears to be just above the entry of the genus Maenioceras and hence close to the base of the widely used Maenioceras Stufe of the goniatite terminology but now to be used excluding the Cabrieroceras crispiforme levels.

\section{Conodont record}

The conodont definition of the Eifelian-Givetian boundary is based on the entry of a definitive form of the conodont species Polygnathus hemiansatus Bultynck (1987) which appears in Bed 123 of the GSSP at Mech Irdane. The Po. hemiansatus lineage was derived most probably from the Po. pseudofoliatus Group. The critical point in the development from Po. pseudofoliatus Wittekindt (1966) to Po. hemiansatus is the transformation from a steep outer anterior margin to an obliquely declining one (Figure 4).

Within the succeeding development of Po. hemiansatus the outer adcarinal trough in front of the geniculation point flattens increasingly. Variations in this flattening can be used for morphometric differentiation within Po. hemiansatus. Two extremes are obvious. One is represented, for instance, by the holotype of Po. hemiansatus (Bultynck, 1987, pl. 7, fig. 26) which demonstrates a flat convex expansion of the anterior outer platform which is strongly bowed outwards, thus forming a spoon-like shelf. This spoon-like structure can be less pronounced in early varieties (Figure 4d) and even more strongly pronounced in late varieties (Figure 4e). A further characteristic feature is a distinct constriction of the outer platform just posterior to the geniculation point where its upper margin forms a high 'shoulder' which arises above the general platform surface.

The opposite extreme also shows a flat slope of the anterior outer platform. The shelf structure, however, is in this case narrower, without a distinct spoon-like expansion, a constriction on the outer platform, or a prominent 'shoulder' (Figure 4c). This variety occurs at the beginning of the range of Po. hemiansatus and, in our samples from pelagic realm facies, is already accompanied by the first specimens of the Po. hemiansatus morphotype with a moderately developed spoon-like structure.

The ancestors of Po. hemiansatus, which are still present with the early Po. hemiansatus morphotypes, have a steep outer anterior platform margin (Figure 4a, b). They are included in the Po. pseudofoliatus Group, typical representatives of which are characterised by deep and narrow anterior adcarinal troughs. Immediate ancestors, however, already demonstrate a slight expansion of the outer anterior platform (for example, in Bultynck, 1989, pl. 2, fig. 5). Also the slope of the anterior outer margin of such Po. pseudofoliatus specimens tends to become shallower, thus indicating the transition to the

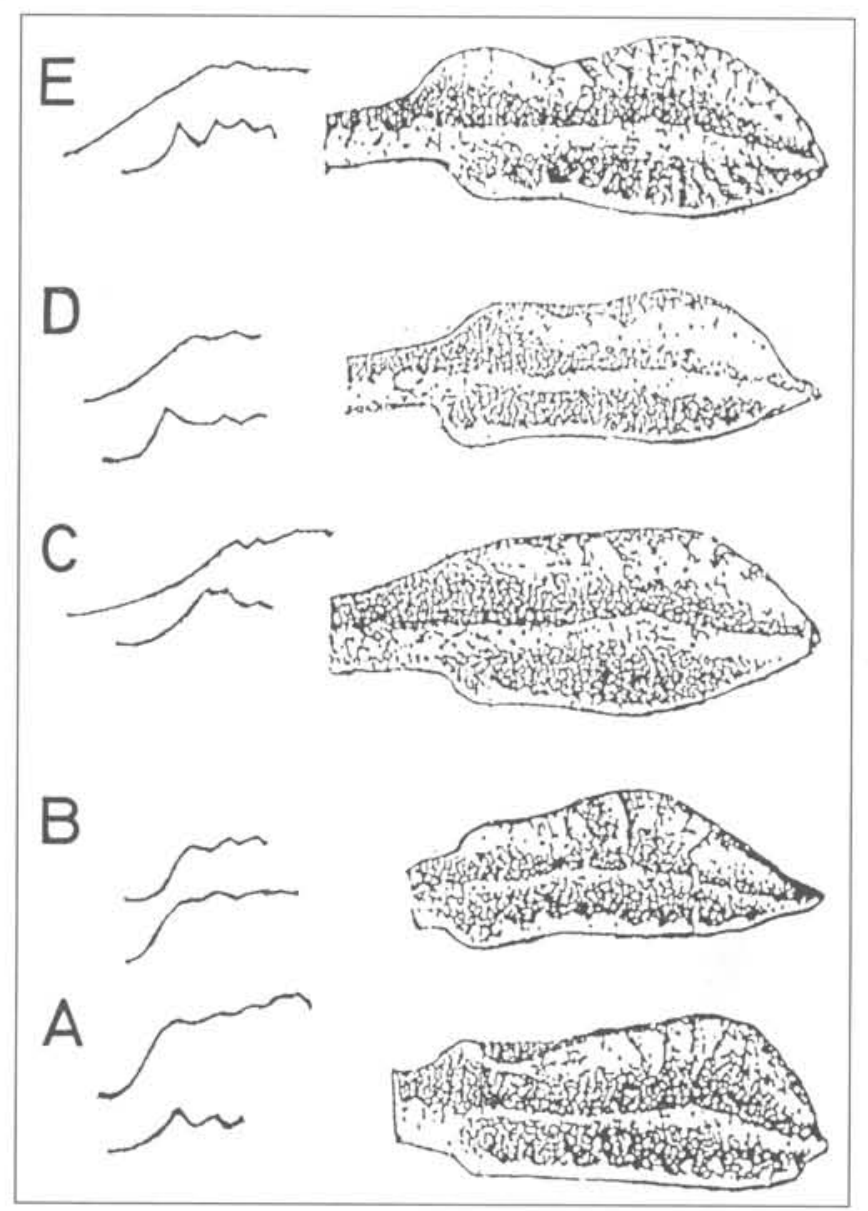

Figure 4 Morphotypes of the conodonts Polygnathus pseudofoliatus-Polygnathus hemiansatus lineage. A, B, Po. pseudofoliatus Wittekindt, with steep outer anterior platform margin; in B, the outer anterior adcarinal trough is already less narrow than in A. C, D, Po. hemiansatus Bultynck, with obliquely declined outer anterior platform margin forming a spoon-like structure; the latter becomes gradually more evident from $C$ to $E$; $D$ coincides with the holotype of $\mathrm{Po}$. hemiansatus. All magnifications ca. $\times 60$. (From Bultynck and others, 1991). 


\begin{tabular}{|cc|}
\hline$D i$ & $F$, \\
$C I$ & $E I$ \\
$B I$ & \\
$A I$ & \\
\hline
\end{tabular}

Figure 6 Sutural diagrams of Middle Devonian goniatites relevant to the Eifelian-Givetian boundary. A-D, Maenioceratidae showing progressive elaboration of the ventrolateral adventitions lobe; $A$, Maenioceras of. koeneni (Frech) from Bed JA/M, Jebel Amelane (MD II-A), Oxford University Museum, House Collection, No. 2476, X 3.5. B, suture of Maenioceras cf: koeneni (Frech) based on Be 1517, Becker Collection, Institute of Palaeontology, Free University Berlin, at whorl height of $9 \mathrm{~mm}$, just before the onset of ventro-lateral furrows, from Bed 119, Mech Irdane (MD II-A), X 4.6. C Maenioceras molarium (Whidborne) reversed sutural diagram of a specimen illustrating an early Givetian zone fossil (MD II-B) from Wolborough Quarry, south Devon, Geological Survey of Great Britain No. GS 7II2, X 4.6; D, Maenioreras terebratum (G, \& $F$. Sandberger) suture illustrating the mid-(ivetian zone fossil (MI) II-C), enlarged. E, F, Tornoceratidae showing the development of the lateral adventitious lobe. $E$, Parodiceras discoideum (Hall), suture based on the holotype from the Cherry Valley Limestone, New York, New York State Maseum 4055, X 3.3. Tornoceras mesopleuron House, the holotype from Thedford, Ontario from beds refered to the early Givetian, X 1.3.

true $P_{0}$. hemicansatus type. Formerly, these transitional forms have been regarded als early varietics of $P$ o. hemiansatus for example, Bultynck, 1987. pl. 7, fig. 22: Weddige, 1988 in range chat of the Freilingen Formation).

The Po. hemiansatus evolution can be demonstrated in two sections of southern Morocco, at Jbel Ou Driss and Jhel Mech Irdane, an well as in the Blauer Bruch section in Germany. In the Jehe! Ou Driss section (Bultynck, 1989), a south-western outlier of the Mäjder Basin. the two earliest morphotypes (sensu Figure 4c. d) occur in sample ODE $7-11$ and specimens similar to the holotype in sample ODE 7-13. In the Mech Irdane section, specimens of Po. hemicansaIIrs are first recognised in sample 123, equivalents of the holotype in samples 125, 127 and 129, and the youngest morphotypes, with extremely developed spoons", in sample 131. In the section of Blatuer Bruch, $P$ o. hemiculsatus appears within the uppermost part of the Odershäuser Limestone (in sample a of the collection of Walliser and sample D2 in the collection of Weddige). The tirst spoon morphotypes" occur within the first massive limestone bed of the overlying discoides Limestone (sample d of Walliser, sample C4 of Weddige).

Intensive studies of the different conodont sequences in Moroce and Central Europe led to the preferred use, which has been accepted, of the lineage of $P$ o. hemiomsatus rather than that of $P o$. ensensis Ziegler and Klapper (1976) which formerly had been taken into consideration as a boundary index (for example. Weddige. 1989). In the sections studied, Fo. ensensis is distinctly less frequent than Po. hemiansatts. This explains why understanding of the evolution of $P O$. consensis is less well known than that of Po. hemransertus. Up to the present it has been recognised that the typical repre- sentatives of $P$ o. ensensis, the anterior platform of which is srongly serrated on both sides. are relatively frequent in levels with spoon morphotypes" of Po. hemiansatus.

Further indicalors for correlation are given by comodonts of the genus leriodus. particularly of the lineage I. regularicescens Bultynck (1970) to 1. obliquimarginatus Bischoff and Ziegles (1957). Transitional forms of both species and early morphotypes of $l$. oblicummarginatus occur with the carlier representatives of $P_{0}$. hemiansatus. But the more typical morphotypes of $I$. oblicluimarginatus, which are charaterised by oblique posterior denticles. accompany the spoon morphotypes of Po. hemiansalus.

\section{Goniatite record}

In the last century Holyapfel (1895) recognised the importance of a goniatite he referred to the enenus Macneceras Hyatt (1884) (ronamed Macmieceras by Schindewolf in 1933). for detining the late Middle Devonian. This has led to the widely recognised Matenieceras Stufe of recent literature replacing the older "Stule des Mateneceras terebratum of Frech $(1902)$. Fomerly the Maenioceras Stufe was approximately equivalent to the Civetian but the SDS/IUGS kecision on the Middle/U pper Devonian series boundary transferred the fomer Frasnien Fla Assise de fromelennes of Begium, and the Adortian be of Germany to the Middle Dewonian (Klapper and others, 1987): House (1985) therefore separaled the zonal equivalent as the Pharriceras Stule as an upper division of the Givetian.

The precise detinition of the lower boundary has until recently been a matter of uncertainty (House. 1978). The defining charater istic of the genus is the phylogeneric entry of an adventitious ventrolateral lobe (ligure 5A, B), thus changing an ancestal anarestid pattern, in which the lateral tobe of the adult migrates laterally during ontogeny, but the ventro-lateral saddke is undivided. The Jebel Mech Irdane stratotype, logether with the adjacent Jebel Amelane section (Becker and House, 1991, 1994a), provides the first detailed documentation of the exact level of entry of the genus Machioceras and family Maeniocerallidae above fammas wih Agrn. costuketus and Cabrieroceres (that is. around beds 112 to 114). The green and marly upper part of bed 119 of the Jebel Mech Irdane section yielded a rich goniatite fauna with numerous Parodiceras. Hol-apfeloceras,

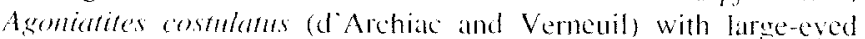
phacopid trilohites. Associated with this fauma but not rare, is the

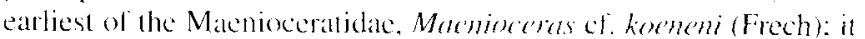
has a shell shape similar to that in Maceniogeras terebratum (G and $F$ Sandberger) (Higure 5D) but with a very shallow adventitious lobe on the ventro-lateral shoulders. The type of Maenio. koseneni (Frech) was from the Montagne Noire. Matnio. andulatum (Holzaplelifrom Germany is somewhat similar but is said to possess rounded rather than angular lateral lobes. find determination must await a revision and illustration of the older species of Maenioceras. A preliminary determination of specimens from Jebel Amelane (Figure $5 \mathrm{~A}$ ) by Becker and House (1994a) has been as Maenio. aft. undulatum but they may be better refered to Maenio. ct. Koeneni. Related forms of about the same age are also known in the upper part of the Kaciak Shale of Bohemia (Holyapfel in Jahn. 1903: Chlupac. 1960) but thes have not been figured. The oldest level with Macnioneras in the Talilalt does not contain any typical Eilelian ammonoid groups. for example Werneroceratinate (Subanarcestes, Cabrieroceras) of Pinacitidae, but only genera known to blossom and range higher in the Givetian. A signifieant faunal change in ammonoid faunas in Moroceo seems to lie within the Kaçak Event interval, at the boundary hetween pyritic shales (Bed 117, with the last abundant Cabrieroceras) and subsequent dacryoconarid-rich carbonates. Thus the base of the Maenioceras Stufe lies only fractionally below the chosen level for the base of the Givetian. and such a small diveroence is accoptable. 
In the Tatilalt. forms which appear to become extinct before the entry of Macnioceras include the Pinacites-Exopinacites Group. Subanarcestes, Fidelites, and the last Anetoceratinae (Kokenid).

The Tornoceratidac appear with Parodiceras in the Eifelian. and Parodiceras is common below the GSSP level al Mech Irdane in the kockeliamus Zone. In New York, Parodiceras oceurs in the Cherry Valley Limestone (Figure 5li) where Tomoceras is also reported (House, 1965) but the typical biconvex growth line pattern is not met until the overlying Chittenango Shale. So it would seem that the true Tornereras enters in the earliest Givetian, but this is not documented in Mech Irdane. Gödderty (1987) has shown that in Algeria, Tornoceras enters logether with feriodes obliquemarginatus. an alternative guide for the earliest Givetian.

Larly Givetian limestones above the boundary at Jebel Mech Irdane have typical agoniatitids and subsequently there is an important regional marker level with small Wedekindella aff. psittacind (Becker and House. 1944a).

\section{Dacryoconarid record}

Detailed study of this group in the area of the GSSP is still needed. Noviakia onomari Boucek and Prantl occurs at Jebel Mech Irdane and in the Tatilatt level but the suleatedotomat \%one boundary as used by Bouces (1964) and laitke (1979) probably lies below the CSSP level and at the base of the Kacík Fevent interval. Alberti (1993) indicaltes that the GSSP level is within the otomari Zone interval. The base of the succeding postotoment Zone is drawn within the rarcus Zone.

\section{Spore record}

For spores, it is the entry of the Gemimosporal lemurata Balme emend. Playford which is a very important tie into terrestrial lacies at though subsequently the species is very long ranging. No spores have yed been obtained from the Jebel Mech Irdane section, but Geminospora lemurata oceurs in Algeria (Blumendjel and others, 1988). In the Eifel this spore enters in the Miillert division of the Ahbach Formation, a little above the GSSP level (Loboriak and others. 1990: Weddige, 1990). The entry has been widely used clsowhere in spore-bearing regions as a guide to the Givetian (Richardson and McGregor, 1986. Streel and others. 1987) and this usage is little altered by the definition proposed

\section{Magnetostratigraphy}

Because of regional renagnetisation. polarity curves have not been produced for the Tafilalt. Nevertheless. new methods of magnetic susceptibility (MS) logging have been undertaken by Crick and oth ers (1995). These studies show the most extreme kevels of low susceptibility associated with the Kacak Event in the Tafilalt with a comparable extreme recorded also at the same level in the Maider Basin. Such studies are continuing.

\section{Chemostratigraphy}

Detailed geochemical studies through the statotype have not yet been attempted. Isotopic fluctuations across the boundary level are currently being investigated in the Broken River area. Quecnsland Australia (Tatent and others 1993) and the same group is working in the Montigne Noire but results are not available. Only preliminary results for the Barrandium are so lat published (Hladilova and others. 1994). However. with such all obvious lithological paroxysm at the Kaçic level it seems unlikely that this will not provide a signa- ture for future use although the level for analysis is likely to depend on biostratigraphic evidence.

\section{Radiometric and OFT dating}

No study provides radiometric dates close to the GSSP for the base of the Givetian. The review of Fordham (1992) suggests a date of about 388 Ma for the boundary. very different from the estimate of $380 \mathrm{Ma}$ by Harland and others (1989). Although an estimate for Givetian time of 6.5 Mat has been given by House (1995) using pre cessional signatures for an Orbital Forcing Timescale (OFT), and estimates have been given for the duration of conodont \%ones for the stage, such work hats not yet been carried down into the Eifelian.

\section{Event stratigraphy}

It is now appreciated that a sedimentary hypoxic perturbation occurs immediately preceding the proposed definition for the base of the Givetian. This otomari Event was recognised by Walliser in 1980 and he gave the name in 1983; he defines the term as the horiyon of facies change 10 black sediments. The term Kaćál Event (House. 1985) has been applied to the whole hypoxic interval. The ofomari or Kačak Event has been increasingly regarded as important in the last few years and it is now recognised in Gemany (Walliser. 1984: Weddige. 1988. 1990; Weddige and Struve, 1988). Spain (TruyólsMassoni and others, 1990; Buggisch and others, 1982) Crech Republic (Ilouse, 1985; Chlupač and Kukal. 1986). North Africal (Walliser, 1988; Becker and House 1994a) and in south-west Asia in the Liujing section of Guangxi (Kuang and others, 1989). In shelf arcas there is evidence that the Kačík or ofomari Event in pelagic sediments is more or less coeval with an interval of gaps which Struve (1982b) described as a "Great Gatp from the neritic Middle Devonian of South-west England, Ardennes. Eifel and even Vietnam (Weddige, 1988; Weddige and Struve. 1988). In continental facies. one of us (MRH) has suggested that the event may he represented in the Old Red Sandstone by the Sandwich and Achanarass Fish beds of Scotland. Neither conodont nor goniatite evidence places it precisely in eastern North America. but the acme of the event may be the deepening and entry of black shales associated with the Chittenango Shate of the early Hamilton Group in New York (House, 1983: Becker and Housc, 1994t. p.110).

Truyols-Massoni and others (1990) drew attention to how loosely the event terms at this level have been applied in recent literature. This is partly due to the successive stages in their recognition. but Devonian hypoxic events are demonstrably polyphase (House, 1985: Schindler, 1990: Becker and House, 1994b) and the chronology of detailed environmental history is only slowly being elucidated. So far as the GSSP section is concerned, the acme would appear to be where the pyritic levels are best developed around beds 11710119.

\section{Correlation of the proposed boundary level}

It has been the view of the Subcommission that sections in pelanic realm facies are likely 10 be more complete than those in neritic facies and it has sought potential stratotype sections which are in pelagic facies with good conodont records and with as many other faunal and floral groups represented ats possible. Following work by Bultynck and Hollard (1980) it was clear that sections in the Tafilalt area of Moroceo were much superior to those known elsewhere. Three proposals were received for potential stratotypes there, at Jebel Ou Driss (Bultynck, 1989; Walliser, 1990, pp.17-23), Bou Tchratine (Bultynck and Walliser in Walliser, 1991, pp.49-57; 
Becker and House, 1994a) and Jebel Mech Irdane (Walliser, 1991, pp.25-29). Jebel Ou Driss, although a thicker section, and containing more neritic elements than Jebel Mech Irdane, was poorer in goniatites. Bou Tchrafine raised problems because there are no limestone beds intercalated in the corresponding upper part of the otomari black shales and the cliff exposures are less accessible. Jebel Mech Irdane, in the event, was preferred because of the greater abundance of pelagic and hemipelagic faunas and excellence of the sections above and below the boundary. Whilst a spore record is not available, it seems probable that this will be forthcoming in readily correlatable localities in view of the records in southern Algeria (Blumendjel and others, 1988). In addition the section at Mech Irdane provides high potential for other fossil groups, especially trilobites and ostracods, but also pelecypods, gastropods, thinshelled brachiopods and even corals.

Because of the wide range of faunal and floral changes at the proposed level, it is considered that the international correlation possible at the entry of Polygnathus hemiansatus is superior to any other level considered by the Subcommission for this GSSP. The main advantage of $P$ o. hemiansatus as an index for the Givetian-Eifelian boundary in comparison with other conodont taxa, is its world-wide geographic distribution. Occurrences are known from the Tafilalt and Maïder of Morocco (Bultynck, 1987, 1989; Walliser, 1988); from the Cantabrian Mountains of Spain (Garcia-Lopez, 1987); from Pic de Bissous in the Montagne Noire of France (Walliser, 1990); from Couvin in the Ardennes of Belgium (Bultynck, 1970, pl.15, fig.5, identified as P. xyla); from Blauer Bruch in the eastern Rhenish Mountains and the Eifel Mountains of Germany (Weddige, 1989); from Guangxi Province of China (Silhongshan section in Ziegler and Wang, 1985, see Bultynck, 1987, pl. 8, fig. 5); and from the Broken River District of Queensland, Australia (Mawson and Talent, 1989).

The proposed boundary coincides closely with the upper boundary of the classical goniatite crispiforme Zone but is below the entry of Stringocephalus and the base of the Calcaire de Givet which has been the most common Belgian and French standard. In this area the earliest occurence of Po. hemiansatus is $42 \mathrm{~m}$ below the base of the Calcaire de Givet. However, it should be stressed that as a consequence of the shallow-water facies, Po. hemiansatus is rare and Icriodus obliquimarginatus is the most valuable boundary index for regional correlation (Bultynck, 1993).

Little work has been done on the precise documentation of groups other than conodonts, goniatites and dacryoconarids across the boundary in other areas, especially when compared with the interest generated by the Frasnian-Famennian extinction event. Nevertheless it does appear to be an extinction event of some importance and, as has been shown, it falls within the range of the various definitions used in Belgium and Germany hitherto. However it is to be expected that the precision of the new conodont data will enable it to be placed with accuracy in many areas of the globe. The Subcommission on Devonian Stratigraphy considers that the new GSSP corresponds closely with classical usages of the basal Givetian and that the more precise definition will do much to stabilise terminology and encourage further study.

\section{References}

Alberti, G K B, 1993, Dacryoconaride und homoctenide Tentaculiten des Unter- und Mittel-Devons I: Courier Forschungsinstitut Senckenberg, v. $158,229 \mathrm{pp}$.

Becker, R T, and House, M R, 1991, Eifelian to early Givetian goniatites at Bou Tchrafine and Jebel Mech Irdane, Tafilalt (Anti-Atlas, S Morocco), in Walliser, $\mathrm{OH}$ (ed.), Morocco Field Meeting of the Subcommission on Devonian Stratigraphy, IUGS, 28 Nov.-4 Dec., 1991, Guide Book. pp. 59-73.

Becker, R T, and House, M R, 1994a, International Devonian goniatite zonation, Emsian to Givetian, with new records from Morocco: Courier Forschungsinstitut Senckenberg, v. 169, pp. 79-135.

Becker, R T, and House, M R, 1994b. Kellwasser Events and goniatite successions in the Devonian of the Montagne Noire with comments on pos- sible causations: Courier Forschungsinstitut Senckenberg, v. 169, pp $45-77$.

Bischoff, $\mathrm{G}$, and Ziegler, W, 1957, Die Conodontenchronologie des Mitteldevons und des tiefsten Oberdevons: Abhandlungen des Hessischen L andesamtes für Bodenforschung, v. 22, pp. $1-1,36$.

Blumendjel, K, I oboziak, S, Paris. F. Stecmans, P. and Streel, M. 1988 Biostratigraphie des miospores et des chitinozoares du Silurien Supéricur et du Dévonien dans le Bassin d’Illizi (SE du Sahara Algérien): Géobios. v. 21 , pp. $329-357$

Bouček, B, 1964, The Tentaculites of Bohemia: their morphology, taxonomy and biostratigraphy: Publishing House of the Czechoslovak Academy of Sciences, Prague, $215 \mathrm{pp}$.

Buggisch, W, Meiburg, P, and Schumann, D. 1982, Facies, paleogeography and intra-Devonian stratigraphic gaps of the Asturo-Leonese Basin (Cantabrian Mts./Spain): Neues Jahrbuch für Geologie und Paläontologie, Abhandlungen, v. 163, pp. 212-229

Bultynck, P, 1970. Révision stratigraphique et paléontologique (brachiopodes et conodontes) de la coupe type de Couvinien: Mémoires de l'Institut Géologique de l'Université de Louvain, v. 26, pp. 1-1.52.

Bultynck, P, 1987. Pelagic and neritic conodont successions from the Givetian of pre-Sahara Morocco and the Ardennes: Bulletin de l'Institut Royal des Sciences Naturelles de Belgique, Sciences de la Terre, v. 57. pp. $149-181$

Bultynck, P, 1989, Conodontes from a potential Eifelian--Givetian Global Boundary Stratotype at Jhel Ou Driss, southern Ma'der, Morocco: Bulletin de l'Institute Royal des sciences naturelles de Belgique. Sciences de la Terre, v. 59, pp. 95-103.

Bultynck, P, 1993. Summary of state of correlation and terminology in the Devonian of the Ardennes resulting from the decision of the S D S: International Union of Geological Sciences, Subcommission on Devonian Stratigraphy, Newsletter No, 10, pp. 33--39.

Bultynck. P, and Hollard. H, 1980. Distribution comparée de conodontes et goniatites Dévoniennes des plaines du Dra, du Ma"der et du Tafilalt (Maroc): Aardkundige Mededelingen, v. 1, 73 pp.

Bultynck. P. Walliser, O H, and Weddigc, K, 1991, Conodont based proposal for the Eifelian--Givetian boundary, in Walliser, $\mathrm{O} \mathrm{H}$, ed., Morocco Field Meeting of the Subcommission on Devonian Stratigraphy, IUGS, 28 Nov. -4 Dec., 1991, Guidebook. pp. 1-15.

Carte géologique détaillée de la France, 1:50000, Feuille XXX-7, Giver 1970, Bureau de Researches géologiques el minières, Orléan.

Chlupáč 1, 1960), Stratigraphical investigation of the Srbsko Beds (Givetian) in the Devonian of Central Bohemia: Sbornik Ustredniho Üstavu Geolického, Oddil Geologicky, v. 26, pp. 143-185 (in Czech with English summary).

Chlupác, I. and Kukal, Z, 1986, Reflection of possible global Devonian events in the Barrandian area, in Walliser. O H. ed., Global bio-events. Lecture Notes in Earth Science, no. 8, pp. 169-179.

Chlupáč I, and Kukal, Z, 1988, Possible global events and the stratigraphy of the Palaeozoic of the Barrandian (Cambrian-Middle Devonian, Czechoslovakia): Sbornik Geologického Védeckého, Geologie, v. 42. pp 83-148.

Crick, R E, Ellwood, B, El Hassani, M, 1994, Integration of biostratigraphy. magnetic susceptibility and relative sea-level change: a new look at high resolution correlation: Subcommission on Devonian Stratigraphy, Newsletter no. 11, pp. 59-66.

Errera, M, Mamet, B, and Sartenaer, P, 1972. Le Calcaire de Givet et le Give tien a Givet: Bulletin de l'Institut Royal des Sciences Naturelles de Belgique, Sciences de la Terre, v. 48 (1), pp. 1-59.

Fordham, B G, 1992, Chronometric calibration of mid-Ordovician to Tour naisian conodont zones: a compilation from recent graphic correlation and isotope studies: Geological Magazine, v. 129, pp. 709-721.

Frech, F, 1902, Über devonische Ammoneen: Beiträge 7ur Paläontologie und Geologie Österreich-Ungarns und des Orients, v. 14, pp. 27-112.

Garcia-Lopez, S, 1987, Los conodontos y su aplicacion al estudio de las divisiones chronostratigrapficas mayores del Devonico Asturleones (Espana): Boletin de geologia y mineria, v. 97, pp. 1-112.

Göddertz, B, 1987, Devonische Goniatiten aus SW-Algerien und ihre strati graphische Einordnung in dic Conodonten-Abfolge: Palaeontographica Abteilung A, v. 197(4-6), pp. 127-220.

Gosselet, J, 1879, Description géologique du canton de Mauberge: Annales de la Société géologique du Nord, v. 6, pp. 129-211.

Harland, W B, Armstrong, R I, Cox, A V, Craig, L E, Smith, A G, and Smith. D $G, 1989$, A geologic time scale, Cambridge University Press, Cambridge.

Hladikova, J, Hladil, J, and Kribek, B, 1994, Carbon isotope record of the Devonian stage boundaries in the Barrandian (Czech Republic): Erlanger Geologische Abhandlungen, v. 122, p. 28 
Holzapfel. E, 1895. Das Obere Mitteldevon (Schichten mit Stringocephalus Burtini und Maeneceras terebratum) im Rheinischen Gebirge: Abhandlungen der Königlichen Preussischen Geologischen Landesanstalt, Neue Folge, v. 16, $459 \mathrm{pp}$.

House, M R, 1978. Devonian ammonoids from the Appalachians and their bearing on international zonation and correlation: Special Papers in Palaeontology, v. $21, v+70 \mathrm{pp}$.

House, M R, 1983, Devonian eustatic events: Proceedings of the Ussher Society, v. 5, pp. 396-405.

House, M R, 1985, Correlation of mid-Palaeozoic ammonoid evolutionary events with global sedimentary perturbations: Nature, London, v. 313 pp. 17-22.

House. M R, 1993, Fluctuations in ammonoid evolution and possible environmental controls, in House, M R, ed., The Ammonoidea: Oxford University Press, pp. 13-34.

House, M R. 1995, Devonian precessional and other signatures for establishing a Givetian timescale: Geological Society Special Publication 85, pp. $37-49$.

Hyatt, A, 1884, Genera of fossil Cephalopods: Proceedings of the Boston Society of Natural History, v. 22, pp. 253-338.

Jahn, J J, 1903, Ueber die Etage $\mathrm{H}$ im mittelböhmischen Devon: Verhandlungen der Kaiserlich-Königlichen Geologischen Reichsanstalt, 1903. No. 4, pp. 73-79.

Klapper, G, Feist, R, and House, M R, 1987, Decision on the boundary stratotype for the Middle/Upper Devonian series boundary: Episodes, v, I0. pp. 97-101

Kuang. G, Zhao, M, and Tao, Y, 1989, Liujing section of Guangxi. The standard Devonian section of China: Guangxi Institute China, China University Geoscience Press, $154 \mathrm{pp}$.

Loboziak, S, Streel, M, and Weddige, K, 1990. Miospores, the lemurata and triangularis levels and their faunal indices near the Eifelian-Givetian Boundary in the Eifel (F R G): Annales de la Société Géologique de Belgique, v. 113, pp. 299-313.

Lütke, F, 1979, Biostratigraphical significance of the Devonian Dacryoconarida: Special Papers in Palaeontology, no. 23, pp. 281-289.

Mawson, R, and Talent, J A, 1989. Late Emsian-Givetian stratigraphy and conodont biofacies - carbonate slope and offshore shoal to sheltered lagoon and nearshore carbonate ramp, Broken River, North Queensland, Australia: Courier Forschungsinstitut Senckenberg, v. 117, pp. 205-259.

Richardson, J, and McGregor, D C, 1986, Silurian and Devonian spore zones of the Old Red Sandstone continent and adjacent regions: Geological Survey of Canada, Bulletin no. 365, pp. 1-79.

Schindewolf, O H, 1933, Vergleichende Morphologie und Phylogenie der Anfangskammern tetrabranchiater Cephalopoden: Abhandlungen der Königlichen Preussischen Geologischen Landesanstalt. Neue Folge, v. $148,115 \mathrm{pp}$.

Schmidt, H, 1926, Beobachtungen über mitteldevonische Zonen-Goniatiten: Senckenbergiana, v. 8, pp. 291-295.

Schmidt, H, 1958, Deutschland, Mittel- und Oberdevon, in Kutscher, F, and Schmidt, H, eds., Lexique Stratigraphique International, v. 1, Europe. Fasc. 5, Allemagne, Fasc 5b, Dévonien, pp. 305-365.

Streel, M, Higgs, K, Loboziak, S, Riegel, W, and Steemans, P, 1987, Spore stratigraphy and correlation with faunas and floras in the type marine Devonian of the Ardenne-Rhenish regions: Revue of Palaeobotany and Palynology, v. 50, pp. 211-219.

Struve, W, 1982a, The Eifelian within the Devonian frame, history, boundaries, definitions: Courier Forschungsinstitut Senckenberg, v, 55, pp. $401-432$.

Struve, W, 1982b. The Great Gap in the record of marine Middle Devonian: Courier Forschungsinstitut Senckenberg, v. 55, pp. 433-448.

Talent, J A, Mawson, R, Andrew, A S, Hamilton, P J, and Whitford, D J. 1993. Middle Paleozoic extinction events: faunal and isotope data: Palaeogeography, Palaeoclimatology, Palaeoecology, v. 104. pp. 139-152.

Truyóls-Massoni, M. Montesinos, J R. Garcia-Alcalde, J L, and Leyva, F. 1990. The Kačák-Otomari Event and its characterization in the Palentine Domain (Cantabrian Zone, NW Spain), in Kauffman, E G, \& Walliser, O H. eds., Extinction Events in Earth History, Lecture Notes in Earth History, v, 30, pp. 133-143.

Walliser, O H, 1980. The geosynclinal development of the Variscides with special regard to the Rhenohercynian Zone, in Cloos, $\mathrm{H}$. and others eds., Mobile Earth; Research Report Deutsche Forschungsgemeinschaft 1980, pp. 185-195.

Walliser, O H, 1983, Statement to the boundaries of the Devonian System, its Series and Stages: Document submitted to the Subcommissionm of Devonian Stratigraphy, Montpellier, 4 pp.
Walliser, O H, 1984, Geological processes and global events: Terra Cognita v. 4, pp. 17-20.

Walliser, O H, 1985, Natural boundaries and Commission boundaries in the Devonian: Courier Forschungsinstitut Senckenberg, v. 75, pp. 401-408.

Walliser, O H, 1988, Proposal for an Eifelian-Givetian boundary stratotype: Document submitted to SDS (ICS, IUGS), Rennes, pp, I-4.

Walliser, O H, 1990. Marble Quarry at Pic de Bissous, Remarks on the stratigraphy: Document submitted to the SDS (ICS, IUGS). Frankfurt am Main, pp. 1,2.

Walliser, O H, ed., 1991, Morocco Field Meeting of the Subcommission on Devonian Stratigraphy, IUGS, 28 Nov.-4 Dec.. 1991. Guidebook, pp. $1-79$.

Weddige. K, 1977. Die Conodonten der Eifel-Stufe im Typusgebiet und in benachbarten Faziesgebieten: Senckenbergiana lethaia, v. 58, pp. $741-419$.

Weddige, K. 1988. Conodont distribution within the Event interval, in Ziegler, W. ed., Ist International Senckenberg Conference and 5th European Conodont Symposium (ECOS IV). Contributions I. Guide to Field Trips. Field Trip A, Eifel Hills: Courier Forschungsinstitut Senckenberg. v. $102,132-133$.

Weddige, K, 1989, Focusing on 'serrated ensensis': Document submitted to the SDS (ICS, IUGS), Washington, pp. 1, 2.

Weddige, K, 1990, Paläozoologie V: Courier Forschungsinstitut Senckenberg, v. 127, 285-288.

Weddige, K, and Struve. W. 1988, Towards a 'natural' Givetian Boundary. Voting for a conodont based boundary close to the culmination of the otomari Event: Document submitted to the SDS (ICS, IUGS), Rennes. pp. $1-42$.

Wittekindt, H, 1966, Zur Conodonten-Chronologie des Mitteldevons: Fortschritte der Geologie von Rheinland und Westfalen, v. 9, pp. $621-641$.

Ziegler, W. and Klapper, G. 1985. Stages of the Devonian System: Episodes, v. 8, pp. 104-109.

Ziegler. W, Klapper, G, and Johnson, J G, 1976, Redefinition and subdivision of the varcus-Zone (Conodonts, Middle-?Upper Devonian) in Europe and North America: Geologica et Palaeontologica, v. 10, pp. 109-140.

Ziegler, W, and Wang, C-Y. 1985, Sihongshan Section, a regional reference section for the Lower-Middle and Middle-Upper Devonian Boundaries in East Asia: Courier Forschungsinstitut Senckenberg, v. 75, pp. 17-37.

Professor Otto Walliser has retired as Professor and Director of the Institute of Geology and Palaeontology at Göttingen University. His research is mainly concentrated on the geosynclinal development of the Variscides, Silurian to Lower Carboniferous stratigraphy and evolutionary processes. He chaired IGCP Project 216, Global Biological Events in Earth History and is a Member of the Subcommissions on Silurian Stratigraphy and on Devonian Stratigraphy.

Dr Pierre Bultynck is head of the department of Palaeontology at the Royal Belgian Institute of Natural Sciences, Brussels and Professor of Palaeontology at the GeographyGeology Department of the Katholieke Universiteit Leuven (Belgium). His research concentrates on Devonian conodont taxonomy and biostratigraphy. He is currently Secretary of the Subcommission on Devonian Stratigraphy.
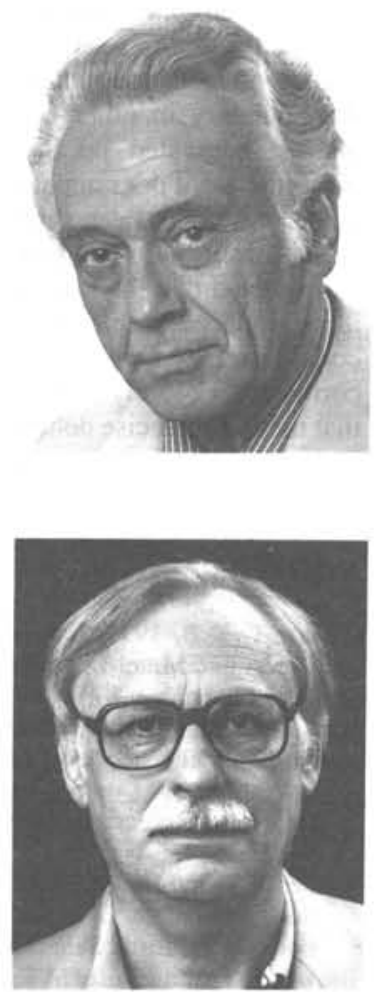
Dr Karsten Weddige, a former pupil of Professor Willi Ziegler at the University of Marburg, has taught at the University of Munich, and is now at the Research Institute of the Senckenberg Museum, Frankfurt. He is engaged in Lower and Middle Devonian conodont studies and was involved in the GSSP recommendations on several Devonian bound aries. Currently he is a Member of the Subcommission on Devonian Stratigraphy and Chairman of the German Subcommission for Devonian Stratigraphy.

Dr $R$ Thomas Becker works at the Palaeontological Institute of the Free University Berlin. He received his doctorate in 1991, from the Ruhr-University of Bochum, Germany, and from 1988-90 worked at the University of Southampton on Devonian extinction events. Currently he is working on global facies shifts and evolutionary ecology in Upper Devonian outer shelf settings. He is a Corresponding Member of the Subcommission on Devonian Stratigraphy.

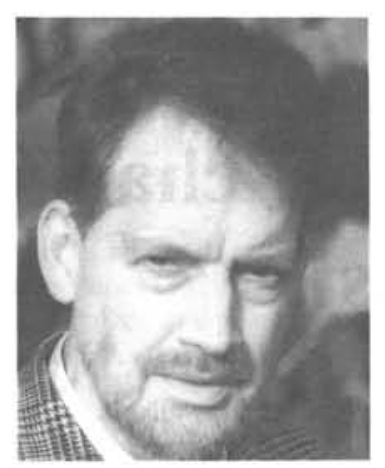

Professor Michael R House is Professor of Geology at the University of Southampton. He had previously taught at the Universities of Durham, Oxford and Hull. His researches have mainly concentrated on mid-Palaeozoic international correlation and regional and event synthesis, mainly using ammonoids. He is currently Chairman of the Subcommission on Devonian Stratigraphy.
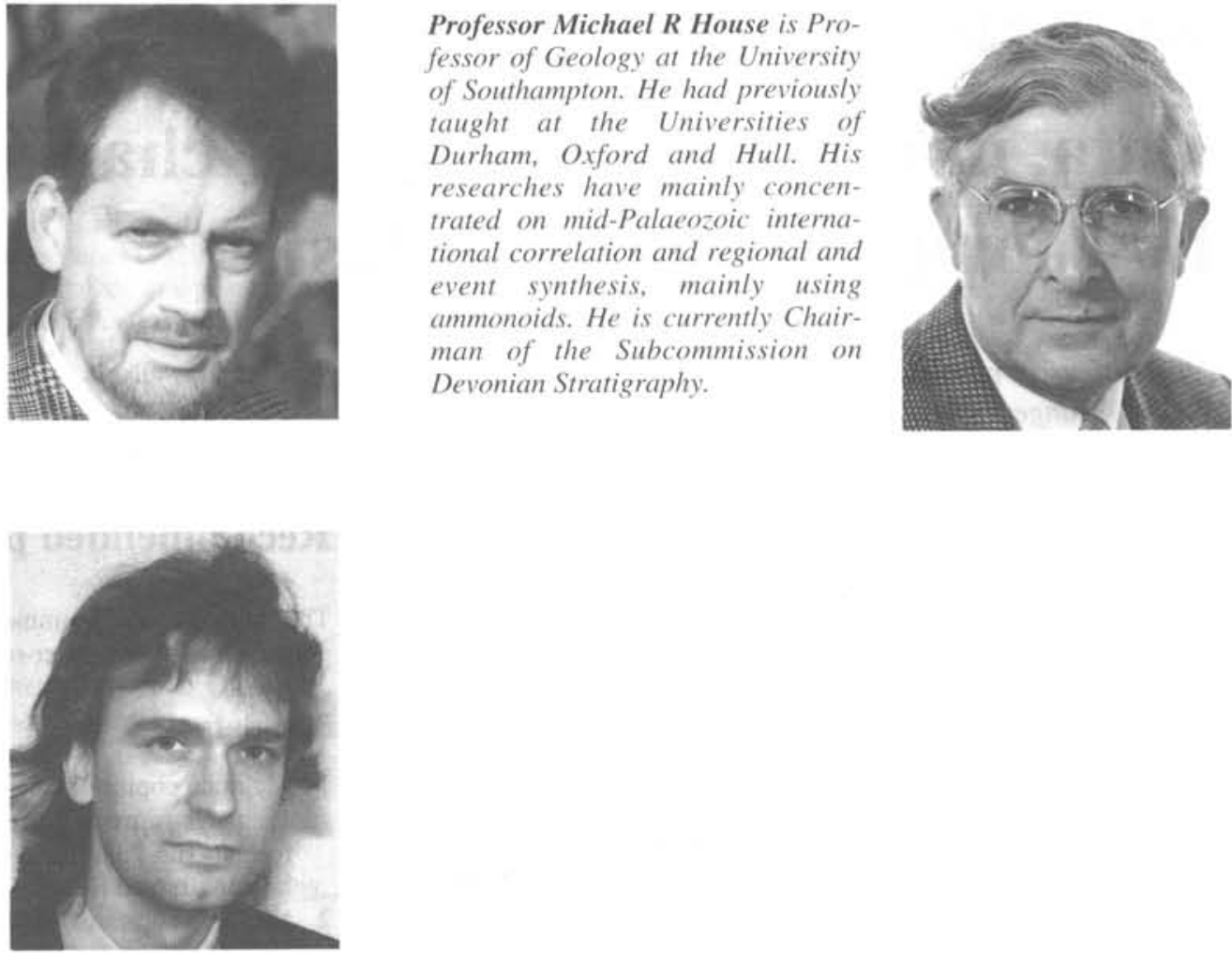